\title{
Soil Microbiome Disruption Used as a Method to Investigate Specific and General Plant-Bacterial Relationships in Three Agroecosystem Soils
}

\section{Michael J DiLegge}

Colorado State University

Daniel K. Manter

Management and Sugar Beet Research, Fort Collins

Jorge Vivanco ( $\sim$ J.vivanco@colostate.edu )

Colorado State Univeristy

\section{Research Article}

Keywords: Agroecosystem, Rhizosphere, Microbiome, Autoclave disruption, Soil microbiology, 16S Sequencing

Posted Date: June 25th, 2021

DOl: https://doi.org/10.21203/rs.3.rs-643243/v1

License: (c) (i) This work is licensed under a Creative Commons Attribution 4.0 International License. Read Full License 


\section{Abstract}

Soil microbiome disruption methods are regularly used to reduce populations of microbial pathogens, which often results in increase crop growth. However, little is known about the effect of soil microbiome disruption on non-pathogenic members within the soil microbiome. Here, we applied soil microbiome disruption, in the form of moist-heat sterilization (autoclaving) to reduce populations of naturally occurring soil microbiota. The disruption was applied to analyze bacterial community rearrangement mediated by four crops (corn, beet, lettuce, and tomato) grown in three historically distinct agroecosystem soils (conventional, organic, and diseased). Applying the soil disruption enhanced plant influence on bacterial colonization, and significantly different bacterial communities were detected between the tested crops. Furthermore, bacterial genera showed significant abundance increases both unique-to and sharedby each tested crop. As an example, corn uniquely promoted abundances of Pseudomonas and Sporocytophaga, regardless of the disrupted soil in which it was grown. Whereas the promotion of Bosea, Dyadobacter and Luteoliobacter was shared by all crops grown in all disrupted soils. In summary, soil disruption followed by crop introduction amplified plant-mediated selection of plant benefiting bacterial genera.

\section{Introduction}

Relationships between crop plants and their native bacterial communities have become increasingly important factors surrounding crop production in agriculture. Recent discoveries have revealed positive correlations between soil microbial diversity and plant health, yield, disease suppression, and soil ecosystem cycling [1-2]. Plants actively recruit rhizosphere microbiota by changing exudation patterns throughout growth to accommodate their developmental needs [3-4]. Thus, cultivation of plants in microbially diverse soils likely provides an assorted selection pool of symbionts that often assist in increasing plant growth [5]. In contrast, several monocultured agroecosystems are indicative of soil microbial dysbiosis, or imbalances in the rhizosphere [6-11]. Such symptoms include reduced soil bacterial diversity [12] and/or microbial imbalances toward higher plant pathogen abundance [6-7, 13]. Further, studies suggest that annual cultivation of the same plant species could allow for a sense of "microbial habituation" to exudates of those plants repeatedly grown in those same sites; thus paving the way for imbalances to occur in soil microbial communities [14]. However, microbial rearrangements in the rhizosphere are not solely attributed to plant rhizodeposition, as the structure and function of the microbiota has also been observed to shift as a consequence of field management practices [15]. Field management may indirectly alter microbial communities, which in turn can instigates variable effects on plant health $[9,16]$.

Recent attempts to reshape imbalances in agroecosystem microbial communities have shown that applying soil sterilization methods (via moist- or dry-heat, chemical fumigation, microwave, or gammairradiation, etc.) can eventually provide a more healthy/balanced rhizosphere microbiome leading to promoted plant growth [17-19]. Other attempts to reduce the negative impacts of imbalanced soil microbial communities on plant health are inoculations with plant-growth promoting rhizobacteria 
(PGPRs) [20]. Such studies often result in the inability of the inoculated microbes to establish, as the native microbiota are habituated to the soil ecosystem and more fit to maintain colonization of the rhizosphere [21-22]. However, it was shown that when the fungicide was applied to disrupt the soil prior to the inoculation of PGPRs, the applied beneficial microbes resulted in higher colonization/establishment compared to the same microbes applied to undisrupted soils [21]. In addition, a recent study shows that applying moist heat sterilization to soils reduced microbial load, which subsequently allowed plants to recruit distinct microbiota from the native community along with several plant growth-promoting microbial functions [17].

In the current study, we further explore the notion that the ability of plants to recruit beneficial bacterial communities is heightened if the soil is exposed to disruption [17]. Here, we applied autoclaving to soil samples collected from three distinct agricultural ecosystems (organic, conventional, and diseased) to disrupt the native microbial communities. Following disruption, crops from four differing families (Poaceae, Amaranthaceae, Asteraceae, and Solanaceae) were planted in the disrupted and undisrupted counterparts of the same soils. Rhizosphere samples were collected from plants grown in each soil after the experiment, and bacterial re-arrangements were analyzed by Illumina MiSeq sequencing of the bacterial 16S gene (V3-V4 region). Interestingly, our results show that several bacterial reads were observed to be increased in abundance both by specific crops, or by two or more crops tested after growth across disrupted soil treatments, which could suggest both generalist- and specific plant-microbe symbioses between crops and the bacterial reads detected.

\section{Methods}

\section{Soil Collection, Treatment and Chemical Analysis}

Soils used in this study were sourced from three agricultural ecosystems. Soil types, plants present during soil collection as well as geographical location of each site are as follows: (i) a USDA-certified organic cover crop field [Agricultural Research, Development and Education Center (ARDEC)-South, Specialty Crops Program, Colorado State University (CSU), Fort Collins, CO] growing mixed cover crop species (Avena sativa and Vicia villosa) and certified as USDA organic since 2003, referred to as "organic soil"; (ii) a USDA ARS no-till cultivation system (ARDEC-North, USDA-ARS, Fort Collins, CO) growing corn (Zea mays) annually supplemented $180 \mathrm{lbs} /$ acre of nitrogen and referred to as "conventional soil" and; (iii) a 10-year old peach orchard (Prunus persica, cv. 'Cresthaven' grafted onto 'Lovell' rootstock; Western Colorado Research Center, Orchard Mesa, Grand Junction, $\mathrm{CO}$ ) that is symptomatic of peach replanting disease and as such is referred to as "diseased soil". Clean shovels were used to collect bulk soil from the organic site at a depth of 20-40 cm after the removal of oat and hairy vetch plants. Thus, the rhizosphere soils of oat and vetch plants were included in the soil collection. Soils from the conventional site were collected similar to the organic site, but corn plants were growing during collection and corn's rhizosphere soils were included. Soils from the diseased site were collected nearby peach tree trunks at a depth of 20$50 \mathrm{~cm} s$ to represent the tree rhizosphere while also being non-destructive to the orchard. 
On collection day all soils were sifted through a No. 10 metal sieve ( $2 \mathrm{~mm}$ wide) prior to autoclave disruption and use in greenhouse experimentation. Sub-samples of each field soil type (organic, conventional, and diseased) were collected, air dried, and stored at $-20^{\circ} \mathrm{C}$ for later DNA extraction. After sieving large debris out of each soil type, soils from each field were divided into two equal parts. The first part of each soil experienced no further treatment and is referred to as undisrupted soil. The second part was exposed to steam sterilization using a STERIS brand autoclave for three 15-minute liquid cycles at $121^{\circ} \mathrm{C}$ and is referred to as the disrupted soil treatment. Standard chemical analyses of all soils were conducted by the Soil, Water and Plant Testing Laboratory at Colorado State University in groups of two replicates per treatment to determine the changes in composition brought upon by autoclaving.

Parameters determined were as follows: $\mathrm{pH}$, electrical conductivity, lime estimate, percent organic matter, soil texture and the following nutrient availabilities were analyzed (in ppm): $\mathrm{NO}_{3}-\mathrm{N}, \mathrm{P}, \mathrm{K}, \mathrm{Zn}, \mathrm{Fe}, \mathrm{Mn}$, and $\mathrm{Cu}$.

\section{Plant Growth Experiment}

The disrupted and undisrupted soils from each site were poured into individual plastic pots $(\sim 400 \mathrm{~g}$ per pot, pot size: $7 \times 10 \times 8.5 \mathrm{~cm}$ ). For each soil treatment, seeds of corn, beet, lettuce, and tomato were surface sterilized with $3.0 \% \mathrm{NaClO}$, rinsed three times with sterile water, and imbibed in sterile water for 24 hours prior to planting. After imbibition seeds were sown into pots at a rate of 3 seeds per pot (with 10 pots per crop per soil treatment; total $n=300$ ). After the emergence of one or more seedlings per pot, extra seedlings were removed to allow for 10 uniform replicates (at a rate of one plant per pot) within a treatment, and then the 7-week growth period began. Additionally, in all treatments, both disrupted and undisrupted soil samples were placed into pots in the absence of plants and included in the experimental block design. These no plant controls (NPCK) provided insights to soil bacterial re-arrangements without the plant inputs. The experiment was conducted at CSU's Horticulture Center Greenhouse Facility under an average temperature of $26.26 \pm 2.17^{\circ} \mathrm{C}\left(79.3 \pm 3.9^{\circ} \mathrm{F}\right)$ and relative humidity of $38.3 \pm 14.5 \%$. To avoid accidental transplanting of soil particles (containing microbes) from differing ecosystems via splashing during irrigation, the experimental replicates were randomized within their respective soil block treatment (i.e. crops in disrupted organic soils were randomized within the disrupted organic soil block). Plants were allowed to grow for 7 weeks and during the 7th week of growth plant growth measurements were recorded.

\section{Plant Experiment - Data Collection}

After the 7th week of growth, plants were harvested, cut at the root-shoot axis and the above-, below- and total fresh-weight biomass measurements of each replicate was recorded. On the same day, rhizosphere soils were collected via gentle brushing of plant roots overtop Ziploc bags to remove any root-adhering soil. Of the ten plant replicates in each treatment, two rhizosphere soil samples (or soil-core samples from the NPCKs, depth: 2-5 cm) were combined for a total of five soil or rhizosphere microbiome samples to represent each experimental treatment. Soil samples were air dried, transported to the lab and stored at $-20^{\circ} \mathrm{C}$ until subsequent DNA extraction. Following fresh-weight biomass measurements and rhizosphere soil collection, plants were placed into individual paper bags, dried in an oven for $48 \mathrm{~h}$ at $65^{\circ} \mathrm{C}$, and then 
the dry-weight biomass was recorded. The mean biomass measurements (both fresh and dry) from each treatment were compared with a two-way ANOVA model using Prism's GraphPad (Vers. 8.2.1) and pairwise comparisons were conducted using Siddak's multiple comparison tests (GraphPad Software, La Jolla California, USA).

\section{Soil DNA Extraction and Bacterial Community Analysis}

Total genomic DNA (gDNA) from 0.25 grams from three out of five soil or rhizosphere samples were extracted using the E.Z.N.A Soil DNA Kit (Omega Bio-Tek, Norcross, GA, USA) according to the manufacturer's instructions. On the same day, nucleic acid concentration and sample purity were quantified and determined via the use of a NanoDrop 2000 Spectrophotometer (Thermofisher, Waltham, MA, USA). gDNA samples were then stored at $-80^{\circ} \mathrm{C}$ prior to Illumina MiSeq library preparation and downstream microbiome analyses.

\section{Microbiome Analyses}

\section{Quantification of Bacterial Cells from gDNA}

Bacterial cell counts per gram of soil were determined by performing quantitative Polymerase Chain Reaction (qPCR) of all gDNA samples against a standard curve of purified Pseudomonas putida KT2440 16s gDNA. For all samples, bacterial cell counts can be interpreted as $P$. putida equivalents per gram of soil. The qPCR conditions were as follows: aliquots of each quantified gDNA sample were collected to prepare template DNA at a concentration of $5 \mathrm{ng} / \mathrm{uL}$. The qPCR reactions were performed in $10 \mathrm{uL}$ reaction volumes containing $1 \mathrm{uL}$ of template DNA and $9 \mathrm{uL}$ of the master mix. The master mix consisted of 5 uL SYBR Green (QuantaBio, Beverly, MA, USA), 0.5 uL of each forward and reverse primer (10 uM) and brought to a total volume of $9 \mathrm{uL}$ using $3 \mathrm{uL}$ of molecular grade water. The qPCR thermal cycling conditions for bacterial quantification were as follows: $95^{\circ} \mathrm{C}$ for 8 minutes and 30 seconds, 30 amplification cycles $\left(95^{\circ} \mathrm{C}\right.$ for 15 seconds, $58^{\circ} \mathrm{C}$ for 30 seconds, $72^{\circ} \mathrm{C}$ for 60 seconds) followed by a final annealing stage at $72{ }^{\circ} \mathrm{C}$ for 5 minutes. The mean cell counts from each crop treatment were compared to their respective NPCK (disrupted or undisrupted) by using a two-way ANOVA model with R Studio's aov function [24].

\section{Library Preparation for Illumina MiSeq Sequencing}

The initial soil gDNA samples were diluted 1:5 with molecular water to reduce PCR inhibitors introduced during DNA extraction. Another round of PCR targeting the V3-V4 region of the bacterial 16S rRNA gene was performed using a modified version of primer set 341F/ 785R (341F: 5'-

TCGTCGGCAGCGTCAGATGTGTATAAGAGACAGCCTACGGGAGGCAGCAG-3'. 785R: 5'-

GTCTCGTGGGCTCGGAGATGTGTATAAGAGACAGGACTACHVGGGTATCTAATCC-3') to target bacterial 16s rRNA and to attach Illumina MiSeq adapters, denoted via underlining in the above primer sequences [25]. This second round of PCR was performed in $20 \mathrm{uL}$ reaction volumes containing $2 \mathrm{uL}$ of template DNA and $18 \mathrm{uL}$ of the master mix. The master mix consisted of $10 \mathrm{uL} 2 X$ Maxima SYBR Green (Thermo Scientific, Waltham, MA, USA), and 2 uL each (10 uM) of forward and reverse primers and brought to a 
total volume of $18 \mathrm{uL}$ using $4 \mathrm{uL}$ of molecular grade water. The PCR thermal cycling conditions were as follows: $95^{\circ} \mathrm{C}$ for 5 minutes, 30 amplification cycles $\left(95^{\circ} \mathrm{C}\right.$ for 40 seconds, $55^{\circ} \mathrm{C}$ for 120 seconds, $72^{\circ} \mathrm{C}$ for 60 seconds) followed by a final annealing stage at $72{ }^{\circ} \mathrm{C}$ for 7 minutes to reduce chimeric reads. A standard curve using purified Psuedomonas putida KT2440 gDNA was run with the samples to quantify the starting rRNA copies per $\mathrm{g}^{-1}$ soil. Resulting amplicons were then purified using an in-house preparation of solid phase reversible immobilization (SPRI) magnetic beads based on a modified protocol of [26] and original protocol of [27].

A second PCR cycle was then conducted to attach unique Illumina Nextera XT indices to each bead cleaned sample for subsequent sample demultiplexing. Each well contained $5 \mathrm{uL}$ of first round and beadcleaned qPCR product, 25 uL of 2X Maxima SYBR Green (Thermo Fisher Scientific, Waltham, MA, USA), 5 $\mathrm{uL}$ each of both forward and reverse indices were combined along with $10 \mathrm{uL}$ of water, bringing the total volume to $50 \mathrm{uL}$. PCR conditions were as follows: $95^{\circ} \mathrm{C}$ for 3 minutes, 8 amplification cycles $\left(95^{\circ} \mathrm{C}\right.$ for 30 seconds, $55^{\circ} \mathrm{C}$ for 30 seconds and $72^{\circ} \mathrm{C}$ for 30 seconds) followed by final annealing of $72^{\circ} \mathrm{C}$ hold for 5 minutes. The resulting PCR product was again SPRI-bead cleaned using the same methods previously mentioned. Amplicons were then quantified using a Qubit fluorometer (Thermo Scientific, Waltham, MA, USA) prior to normalization and pooling. The final pool was run on a TapeStation system (Agilent Technologies, Santa Clara, CA, USA) to determine size and purity of amplicons, and Kapa Biosystems (Sigma-Aldrich, St Louis, MO, USA) qPCR was performed according to the manufacturers' instructions to determine concentration. The final pooled sample was diluted to $4 \mathrm{nM}$ and the DNA library was denatured with $0.2 \mathrm{~N} \mathrm{NaOH}$, diluted to $10 \mathrm{pM}$ using provided HT1 buffer, and spiked with 20\% PhiX library standard diversity-control. Illumina's MiSeq v3 600-cycle Reagent Kit (Illumina, San Diego, USA) was used for library dilution and loading onto the MiSeq at CSU's Next Generation Sequencing Laboratory (Fort Collins, $\mathrm{CO})$.

\section{Bacterial 16s rRNA gene sequence analysis}

De-multiplexed raw fastq files were processed with the DADA2 pipeline using R Studio's Bioconductor packages [28]. Briefly, all primers were removed from each sequence using the open source Python program Cutadapt [29] and amplicon sequence variants were inferred using the default pipeline in DADA2. Each sequence variant identified in DADA2 was classified to the closest reference sequence contained within the Silva reference database (Version 132). Each taxonomic profile assigned was used to determine bacterial genus level abundance values. Downstream analyses were conducted using $R$ Studio's Phyloseq and vegan packages or myPhyloDB (vers. 1.2.0) [30-32]. Samples were rarified at a cutoff of 7500 reads using myPhyloDB prior to downstream analysis applications using myPhyloDB or $\mathrm{R}$ Studio. Measurements of a-diversity assigned to treatments were determined using the Shannon diversity index, as this diversity measure accounts for both richness and evenness within each sample. A two-way ANOVA model was applied to compare mean a-diversity values from each disrupted crop treatment to their respective undisrupted crop treatment. Additionally, disrupted crop treatments were compared to the disrupted NPCK treatments with R Studio's Analysis of Variance package [24]. R Studio's vegan package was used with the Bray-Curtis dissimilarity index to quantify differences in phylogeny and diversity 
between samples from different treatments [30]. Distances were visualized using principal coordinates analyses (PCoA) created using Prism's GraphPad (Vers 8.2.1, GraphPad Software, La Jolla California, USA). The myPhyloDB software was used to perform a complementary non-parametric multivariate statistical test, including permutational analysis of variance (perMANOVA) as well as differential abundance analyses (FDR < 0.1) to test for differences in microbial communities between treatments [32]. A Venn diagram of these data was constructed using the jvenn software [33].

\section{Results}

\section{Soil Chemical Analysis}

To determine the effect of autoclave disruption treatment on soils, soil pH, electrical conductivity, lime estimate, percent organic matter, texture and parts per-million ( $\mathrm{ppm}$ ) of the following nutrients: nitratenitrogen, phosphorous, potassium, zinc, iron, manganese, and copper were measured. These parameters were analyzed for all disrupted and undisrupted soil samples (Table 1). Across all soil sites, phosphorous and manganese were significantly increased due to autoclave disruption. For organic soil, $\mathrm{P}$ and $\mathrm{Mn}$ were increased by 0.299 -fold ( $p$-value 0.004 ) and 2.292-fold ( $p$-value: $<0.001$ ), respectively (Table 1). For conventional soil, $\mathrm{P}$ and $\mathrm{Mn}$ were increased by 0.462 -fold ( $\mathrm{p}$-value: 0.002 ) and 1.792-fold ( $\mathrm{p}$-value: < 0.001 ), respectively (Table 1 ). For diseased soil, $P$ and $M n$ were increased by 0.241 -fold ( $p$-value: 0.016 ), and 7.571-fold ( $p$-values: $<0.001$ ), respectively (Table 1). Interestingly, only the diseased agroecosystem soil experienced significant reductions in the availability of both zinc (0.137-fold, p-value: 0.002$)$ and copper (0.318-fold, $p$-value: $<0.001)$ after autoclaving. Neither organic nor conventional soil experienced significant reductions in nutrient availability after autoclave disruption (Table 1).

\section{Plant Growth Experiment}

Above and below ground measurements of plant dry-weight (DW) biomass were added to analyze disruption effects on total DW biomass of crops (Fig. 1). The total DW biomass of corn was significantly increased when compared to total DW of corn grown in soils with no disruption ( $p$-values: $<0.001,<$ 0.001 , and $<0.001$ for organic, conventional, and diseased; respectively). The total DW biomass of beet was significantly promoted when grown in disrupted organic and disrupted conventional soils ( $p$-values: 0.012 and 0.008 for organic and conventional; respectively), but not in the diseased soil. Total DW biomass of tomato was not significantly altered after growth in any of the disrupted soils. Lastly, the total DW of lettuce was significantly increased after growth in disrupted conventional and disrupted diseased soils ( $p$-values: $<0.0001$ and 0.049 for conventional and diseased; respectively), but not in the disrupted organic soil. Tables displaying the average gain in DW biomass, fresh weight biomass bar graphs (Supplemental Figure S1), and percent increases observed for each treatment can be visualized in Supplemental Tables S1 \& S2.

\section{Microbiome Analyses}




\section{qPCR Bacterial cell quantification}

For all soil gDNA samples, the final concentration of nucleic acids ranged from $15.2 \pm 8.6 \mathrm{ng} / \mathrm{uL}$ after extraction. For qPCR analysis, bacterial cell counts from the no plant control samples (NPCKs) for each agroecosystem (disrupted or undisrupted) were compared to cell counts from crops to see changes in bacterial cells as a result of crop growth in disrupted or undisrupted soils. In organic soils, our qPCR analysis shows no significant differences observed between soils with crops compared to the NPCKs, regardless of disruption (Fig. 2A). For conventional soils, no significant differences in bacterial cell counts were observed between the undisrupted NPCKs and the undisrupted soil that grew crops. After disruption of the conventional soils, the lettuce rhizosphere had significant promotions in bacterial cell counts, compared to the disrupted conventional NPCK (p-value: 0.011, Fig. 2B). In diseased soil, the growth of corn in undisrupted soil allowed for a significant increase in bacterial cells, compared to cell counts from the undisrupted diseased NPCKs (p-value: 0.004, Fig. 2C). Furthermore, after applying disruption to the diseased soil there were no significant differences in bacterial cell counts observed between treatments and the NPCKs (Fig. 2C).

Interestingly, the NPCKs provided insights into soil bacterial rearrangements occurring in the absence of plants following disruption. In both the organic and conventional soils, soil bacterial trends followed those observed when crops were introduced to these systems after disruption (e.g. cell counts were lessened after disruption compared to their undisrupted counterparts). However, in the diseased soil bacterial cell counts from the disrupted NPCKs were not significantly different form the undisrupted soils (p-value: 0.975). The associated statistical analysis for these data can be visualized in Supplemental Table S3.

\section{Illumina MiSeq data}

After filtering reads, removing singleton ASVs and rarifying, Illumina MiSeq paired-end sequencing generated a total of 4,264,022 reads resulting in an average of 46,348 reads per sample. Seven out of 104 total samples did not meet rarefaction criteria (min. 7,500 reads) and were dropped. Bacterial diversity resulting from crop growth in disrupted soils were compared to their disrupted NPCKs within the same agroecosystem. Additional comparisons were made from the disrupted crop growth treatments to their crop-counterparts grown in the undisrupted parts of the same soil. Bacterial diversity (Shannon index) was significantly different between communities from the disrupted and undisrupted corn grown in the diseased agroecosystem ( $p$-value 0.041 ) but not for any other plant/soil combination (Table 2, Supplemental Table S4).

\section{Principle coordinate analysis of rhizobacterial community rearrangements}

In the organic soils, a permutational analysis of variance using distance matrices revealed that microbiome disruption resulted in significant differences in bacterial community phylogeny (disruption pvalue: $0.001, R^{2}: 0.549$, Axis.1: $56.14 \%$ ) for the organic soils. Furthermore, our analyses revealed that each 
crop family was able to recruit significantly different rhizobacteria independent of disruption (crop effect p-value: $0.001, R^{2}$ : 0.1372, Axis.2: $6.06 \%$ ) (Fig. 3). A secondary beta-diversity analysis using betadisper further demonstrates that after the organic soils were disrupted, individual crops were able to recruit significantly different rhizobacterial communities from the same crops grown in undisrupted organic soil (p-value 0.027).

In the conventional soil, our analyses showed that disruption produced the strongest significant differences in bacterial community phylogeny (disruption p-value: 0.001, $\mathrm{R}^{2}$ : 0.693, Axis.1: 69.59\%) when comparing reads from disrupted to the undisrupted conventional soil. Furthermore, crops grown in conventional soil were able to recruit significantly different rhizobacteria by plant-family, whether or not disruption occurred (crop effect p-value: 0.001, R²: 0.060, Axis.2: 3.95\%) (Fig. 4). Our complimentary betadiversity analysis also showed that once disrupted, crops could recruit significantly different rhizobacterial communities from their same-crop counterpart grown in undisrupted conventional soil ( $p$ value 0.015) (Fig. 4).

The diseased soil demonstrated the weakest effect regarding microbiome disruption. Again, soil disruption also resulted in significantly different bacterial communities when comparing reads from the disrupted to undisrupted diseased soil (disruption p-value: 0.001, $\mathrm{R}^{2}$ : 0.461, Axis.1: 47.85\%). Still, in diseased soils each individual crop family recruited significantly different rhizobacteria from other crop families regardless of disruption (crop-effect p-value: 0.001, $R^{2}$ : 0.148, Axis.2: 15.56\%) (Fig. 5). The betadiversity analysis for the disrupted and undisrupted diseased agroecosystems samples revealed that crops of the same plant were unable to recruit significantly different rhizobacterial communities from their counterpart (i.e. the same crop in undisrupted diseased soil) (p-value 0.08).

\section{Rhizobacteria recruited by crops vs No Plant Controls (NPCKs) in undisrupted and disrupted soils}

In both undisrupted and disrupted treatments, bacteria showing significant alterations in abundance values were pooled across all three soil agroecosystems and grouped by crop type. The abundances of these bacteria from each crop were then compared to the respective pooled NPCK samples (undisrupted or disrupted) to attribute abundance alterations to plant presence. Differential abundance analyses revealed significantly altered bacterial genera resulting from crop presence (Tables $3-4)$. Across the pooled undisrupted treatments, four bacterial genera were significantly altered in abundance by crop presence (Table 3), whereas twelve bacterial genera were altered in abundance when crops were grown across the pooled disrupted treatments (Table 4). Specific genera altered in abundance by each individual crop, when compared to the no plant control samples, can be visualized in Tables $3 \& 4$

\section{Differences in bacterial recruitment by the same crops in disrupted vs undisrupted soils}

The ability for crops to alter abundance of bacterial genera during growth in the disrupted soils, compared to their same-crop counterpart in undisrupted soils, was also of interest. Across all disrupted 
soils, corn growth resulted in significantly increased abundances of 29 bacterial following genera compared to corn growth in undisrupted soil (Table 5). Beet plants growth in disrupted soils significantly increased the abundances of 16 bacterial genera (Table 6). Lettuce growth in the disrupted soils significantly increased abundances of 29 bacterial genera (Table 7) Lastly, tomato growth in disrupted soils significantly increased abundances of 20 bacterial genera (Table 8 ). The bacterial genera increased in the disrupted no plant controls were reported (Table 9) and genera were filtered out from the crop tables (Tables 5-8) to attribute abundance increases to plant presence.

\section{Shared bacterial abundance increases among crops following soil disruption}

Across all disrupted soils, growth of corn, beet, lettuce, and tomato significantly increased abundances of several unique and overlapping bacterial genera (Fig. 5, Supplemental Table S5). However, if bacterial genera were observed to increase in the disrupted NPCKs, these genera were filtered out as bacteria able to proliferate in the absence of a plant (Table 9). Across all disrupted agroecosystems, all four crops significantly promoted the abundance of eleven bacterial genera, and two bacterial families (Fig. 5, Supplemental Table S5). A total of nine other bacterial genus level reads were significantly increased in abundance and shared by different combinations of three out of the four crops tested. Corn, lettuce, and tomato growth increased the abundance of bacterial families Cellvibrionaceae, Fibrobacteraceae, and KD3-93. Beet, tomato, and lettuce increased the genera Algoriphagus, Devosia, Oligoflexus and Articibacter. Beet, corn, and tomato growth increased abundances of the family Devosiaceae and the genus Opitutus (Fig. 5, Supplemental Table S5).

Several other bacterial genera were observed to be increased in abundance and shared in the rhizosphere by different combinations of only two out of the four crops. Bacterial genera increased by the growth of tomato and lettuce were Anoxybacillus, Flavobacterium, PCC-7104 and Verrucomicrobium, in addition to the families Beijerinckiacea and Cyclobacteriaceae. Corn and lettuce growth promoted abundances of the bacterial orders Bacillales and Candidatus_Peribacteria. Corn and tomato growth increased abundances of the genus Stenotrophomonas. Beet and lettuce both increased abundances of the genera Quadrisphaera, Brevibacillys, SH-PL14, and Roseomicrobium, in addition to the family Sphingomonadaceae and the order Sericytochromatia. Beet and tomato both promoted abundances of the genus Ammoniphilus, whereas the growth of both beet and corn promoted the genus Caulobacter and the order Microgenomatia (Supplemental Table S5).

\section{Crop-specific bacterial abundance increases following soil disruption}

There were also several crop-specific bacterial reads increased in abundance following soil disruption. For example, corn growth significantly promoted abundances of two genera (Sporocytophage and Pseudomonas) along with two families (Fibrobacteraceae and Rhodothermaceae) (Fig. 5, Supplemental Table S5). Growth of beet promoted abundances of six genera (Roseococcus, Peredibacter, Flavisolibacter, Parasegetibacter, UTBCD1 and Solimonas) (Fig. 5, Supplemental Table S5). Nine bacterial 
genera were increased in abundance in response to lettuce growth (Rhodobastu, Roseomonas, Rhodoferax, Fluviicola, Cytophaga, Knoellia, PCC-6304, Tepidisphaera, and Brevifollis). Lettuce growth also increased abundance of four bacterial families (Burkholderiaceae, Caulobacteraceae, Opitutaceae, and Sporolactobacillaceae) (Fig. 5, Supplemental Table 5). The growth of tomato increased abundance of nine bacterial genera (Bacillus, Chelatococcus, Asticcacaulis, Yongharparkia, Aminobacter, Cereibacter, Mucilaginibacter, Shimazuella, and Thermomonas), three bacterial families (Archangiaceae, Hydrogenedensaceae, and Verrucomicrobiaceae) and two orders (Candidatus_Peribacteria and Candidatus_Pacebacteria) (Fig. 5, Supplemental Table S5).

\section{Discussion}

\section{Effects of autoclave disruption on agroecosystem soils}

Distinct field management techniques (organic, conventional, or disease management-focused) indirectly condition native soil microbes to variable degrees, and these changes in microbiota in turn may positively or negatively impact plant growth $[6-7,16,18]$. Here, we investigated how soil factors (both biological and chemical) in three distinct cropping systems responded to autoclave disruption, and how these responses could have impacted plant growth. Soil autoclaving has been shown to increase extractable $P$ and $\mathrm{Mn}$ content [34-35] and this was also observed in all soils tested in our study. Interestingly and unique to the diseased soil, both $\mathrm{Zn}$ and $\mathrm{Cu}$ content were reduced after disruption. Similarly to [17] plant growth promotions were also observed for each crop when grown in disputed soils, compared the same crops grown undisrupted soil counterparts. These increased plant growth effects are probably not a result of increased $\mathrm{P}$ and, Mn content, but more likely are attributed to the effects of disruption on soil microbiota. Our 16S qPCR analysis revealed variable changes on bacterial biomass resulting from disruption and crop growth, with most bacterial populations being reduced compared to undisrupted samples. As such, the increased plant growth result may be due to i) disruption reducing plant-microbe competition for soil resources, or ii) the reduced population of bacteria allowed for lessened bacteriabacteria competition for plant deposited resources favoring the recruitment of plant growth promoting taxa.

\section{Effects of autoclave soil disruption on rhizobacterial community dynamics}

Upon collection, it was observed that a higher bacterial diversity level (Shannon Index) persisted in the conventional and diseased soils compared to the organic site. However, autoclave disruption and plant growth induced the organic site to manifest the highest value of bacterial diversity out of all three soils. It was also observed that following growth in the disrupted soils, plants were able to recruit a greater number of bacterial genera (12 genera) compared to their growth in undisrupted soils (4 genera). Combining the observations shared by disrupting three distinct soils (increased plant growth, Shannon's diversity index, and number of recruited genera following disruption); soil disruption may likely serve as a promising managerial technique in restoration of soil microbiota imbalances. 


\section{Principal coordinate analysis of rhizobacterial communities}

Soil disruption also caused significantly different bacterial community phylogeny from the undisrupted soils, across all sites [Bray Curtis distance, disruption p-values: 0.001 (for all soils)]. These findings demonstrate that each crop was able to recruit significantly different rhizobacteria, based upon the soil in which the crop was grown and whether disruption (or no disruption) was administered. The strongest effect of crop-specific recruitment can be exemplified in the organic soil. Each crop was shown to promote distinct rhizobacteria, both when comparing the crop to its undisrupted counterpart, as well as comparing differing crop rhizobacteria to one another when all were grown in disrupted or undisrupted sites (disruption effect p-value: 0.001, Axis.1: 57.14\%; crop effect p-value: 0.001, Axis.2: 6.06\%; $\mathrm{R}^{2}$ : 0.1372).

Similarly to the organic site, crops grown in conventional soil were also able to recruit significantly different communities between different crops and also between the same crops in disrupted or undisrupted soil (disruption effect p-value: 0.001, Axis.1: 69.51\%; crop effect p-value: 0.001, Axis.2: 3.95\%; $R^{2}$ : 0.060). Conventional management practice often employs synthetic fertilizers and broad-spectrum pest- or herbicides, which can result in detrimental effects on bacterial evenness [36-37]. Albeit these negative effects on microbiota from conventional management, bacteria in the conventional agroecosystem site were still able to be reshaped by plants like those in the organic agroecosystem. Furthermore, a beta diversity analysis again confirmed that crops grown in disrupted conventional soils were able to recruit significantly different bacteria compared to the same crop families growing in undisrupted conventional soils ( $\mathrm{p}$-value 0.015 ) suggesting significant bacterial community alterations, mediated by plants following disruption in both conventional and organic soil.

The different crops grown in the diseased soils were also able to recruit different rhizobacterial communities from one another (crop-effect p-value 0.001, $R^{2}$ : 0.148, Axis.2: 15.56\%). Interestingly, disrupting diseased soil did not allow the crops to recruit different bacteria from their counterparts in the undisrupted soil (p-value: 0.080 ). A potential explanation of this could be based on the presence of Bacillus and Colstridium genera, as these can survive heat treatment by the formation of thermotolerant endospores [38]. Thus, if these genera had survived autoclaving would likely dominate crop rhizocommunities when grown in the diseased soil. Relative abundance (RA) values of Bacillus in pooled samples of undisrupted organic, conventional, or diseased soils were $0.036,0.006$, and 0.049 , respectively. Whereas the RA of Clostridium were $<0.001,<0.001$, and 0.001 in undisrupted organic, conventional, and diseased soil, respectively. After disrupting each organic, conventional, or diseased soil; the RA of Bacillus increased to 0.085, 0.080, and 0.118; Clostridium RA was promoted to 0.001, 0.003, or remained the same at 0.001 for organic, conventional, and diseased respectively (data not shown). Thus, in our study the mentioned spore-forming genera increased in abundance after autoclaving and crop growth, with the highest increase in RA being observed by Bacillus in the diseased agroecosystem.

In support of this observation, our 16s qPCR assay shows that only bacterial cells in the diseased agroecosystem increased in the NPCKs (no plant control samples) after disruption, suggesting potential 
proliferation of thermotolerant bacteria after a likely reduction in bacterial resource competition brought upon by autoclave disruption. Accordingly, we hypothesize that this disruption provided favorable environments for thermotolerant taxa to multiply in the diseased agroecosystem (and to a lesser degree in other sites) while limiting the number of plant-available bacteria for recruitment.

\section{Crop-shared bacterial genera recruited following agroecosystem disruption}

Our differential abundance analyses revealed several bacterial abundance increases overlapping between different crops after growth across all soils following disruption (Supplemental Table S5). Eleven genera and two families (Bosea, Caenimonas, Brevundimonas, Lacibacter, Luteolibacter, Pedobacter, Sphingoaurantiacus, Sphingopyxis, Dyadobacter, Larkinella, Rhabdobacter and families Saccharimonadaceae and Sphingobacteriaceae; Supplemental Table S5) were observed to increase in abundance following disruption and growth of all four crops. We hypothesize that crops formed associations with some of these genera due to previous reports surrounding their plant growth promotional (or plant-symbiotic) nature. For example, members of Bosea and Sphingopyxis genera have been described to be PGPRs; and members of Bosea spp. can produce the auxin IAA [39-40]. When Dyadobacterspp. were inoculated into soil, previous results showed the genus was positively correlated with nitrogen fixation and increased nitrate reductase activity in plant leaves [41]. Additionally, Brevundimonas, Pedobacter, Luteoliobacter, Lacibacter, and Caenimonas have all been isolated from the root communities of different plants [42-46]. Lastly, Larkinella, Rhabdobacter and Sphingoaurantiacus are genera that have been previously isolated from organic amendments (Larkinella) or soil systems (Rhabdobacter and Sphingoaurantiacus) [47-49].

Abundances of other bacterial genera were increased as a result of specific recruitment by three out of the four crops (but not all crops like those previously mentioned) following disruption, and these trends were also observed across pooled disrupted soils. The crop combinations that significantly increased the abundance of five bacterial genera (Algoriphagus, Articibacter, Devosia, Oligoflexus, and Opitutus) can be visualized in Supplemental Table S5 and additionally, these shared genera are reported to possess some potential PGP ability. Both Opitutus and Devosia genera were seen to be associated with rice rhizosphere [50-51], and studies show that members of the Devosia genus possess a myriad of plant-benefiting functions (IAA synthesis, production of ammonia, and production of siderophores) [52-53]. Additionally, the Devosia genus has been identified to comprise true plant-endophytes that colonize the interior tissues of tomato plants [54]. Algoriphagus has been observed to increase in relative abundance as a response to plant defense inducing biochemicals (salicylic acid, methyl jasmonate, and abscisic acid) [55]. The notion that Algoriphagus shows increased abundance in response to plant-defense compounds may suggest an upregulation of plant-defenses carried out by members within the genus. Literature on Articibacter spp. is scant, but the genus is prevalent in soybean rhizosphere during the vegetative stage [56]. In addition, Oligoflexus tunisiensis was isolated from the rhizosphere of both buckwheat and barley [57]. Several other shared bacterial taxa by two of the four crop combinations can be visualized in Supplemental Table S5. 


\section{Crop-specific bacterial genera resulting from agroecosystem disruption}

There were also observations of several potential PGPR genera specifically increased by individual crops across the pooled disrupted soils. The bacteria increased by beet were Roseococus, Peredibacter, Flavisolibacter, Parasegetibacter, UTBCD1 and Solimonas. The genus Roseococcus falls within the family Acetobacteraceae which has been associated with nitrogen fixation and PGP-ability [58]. Peredibacter spp. are soil bacteria that are bacterivorous toward gram-negative bacteria, suggesting a biocontrol ability of pathogenic bacteria by members of the Peredibacter genus [59]. Other studies show increased relative abundances of the genus when tomato plants were inoculated with the PGPR Pseudomonas sp. RU47 [60]. Flavisolibacter is a genus positively correlated with disease suppression of Rhizoctonia solani [61]. The understudied Parasegetibacter and UTBCD1 genera falls within the Chitinophagaceae family, and this family is comprised of genera recorded to possess plant-growth promotional ability [62-63]. Lastly, members of Solimonas have been isolated from agricultural soils growing ginseng [64].

Corn growth significantly increased abundances of the genera Sporocytophaga and Pseudomonas in addition to the families Fibrobacteraceae and Rhodothermaceae. Of the promoted bacterial genera by corn, only Pseudomonas members have been extensively documented due to their plant growth promotional abilities [65-67]. However, the genus Sporocytophaga is widespread in soils and members such as $S$. myxococcoides can hydrolyze cellulose [68]. Additionally, the Rhodothermaceae family bacteria also possess cellulolytic and xylanolytic activity [69]. Likely both Rhodothermaceae and Sporocytophaga members aid soil ecosystem in cycling of plant detritus, exuding carbon sources for neighboring, potentially plant-benefiting microbes. Lastly, the family Fibrobacteraceae has been recorded to closely associate with wheat, which is in the same plant family as corn (Poaceae) [70].

Lettuce growth promoted the abundance of 17 bacterial taxa, and four of the promoted genera have been associated with plant symbiotic or protective abilities (Rhodoferax, Fluviicola, Cytophaga, and Knoellia). Rhodoferax members can degrade chemical herbicides [71], and Fluviicola is a common member of the rice rhizosphere [56]. Bacteria within the genus Cytophaga are present in the barley rhizosphere, and may contribute to the turnover of carbon, phosphorus, and nitrogen in soil ecosystems [72]. Lastly, a species within the Knoellia genus was considered an endophyte of Costus speciosus (a type of ginger) [73].

Tomato growth in disrupted soils promoted nine bacterial genera (Bacillus, Chelatococcus, Asticcacaulis, Yonghaparkia, Aminobacter, Cereibacter, Mucilaginibacter, Shimazuella, and Thermomonas). Bacillus members are known genera documented on their plant growth promotional abilities [74-76], and Bacillus and Asticcacaulis were both considered members of the tomato endospheric bacterial community [77]. Two Muciliginibacter spp. were recently discovered to be PGPRs by increasing root length of tomato [78]. Shimazuella falls within the actinomycetes phylum and was isolated from Pueraria candollei (Kudzu) rhizosphere soil [79]. Another genus promoted by tomato, Yonghaparkia, can utilize the precursor to ethylene, ACC (1-Aminocyclopropane-1-carboxylic acid), as a nitrogen source [80]. Aminobacter members can produce the plant growth hormone cytokinin [81]. Lastly, some Thermomonas members are 
thermotolerant [82] explaining how these taxa were able to withstand disruption, although the literature on the relationship between genus and plants is lacking.

\section{Importance of crop shared bacterial abundance increases following disruption}

Our data showed that several PGPR-related genera were significantly increased in abundance and associated with all crops tested when grown in soils following disruption. Accordingly, we speculate that plant rhizodeposition during early growth and development plays a strong contribution to fill "empty" niches (here "emptied" by disruption) with plant symbiotic and/or beneficial taxa. Since our experiment occurred during the first seven weeks of crop-growth, it is possible that some of these crop-shared genera could represent generalist-PGPRs, plant-symbiotic taxa, or bacterial keystone species; and keystone species are described as low abundance early colonizers that aid in the establishment of the plant's core microbiome [83-85].

While all crop-shared bacteria may not represent keystone species, instead these may indicate understudied or novel PGPRs. As an example, observations of Luteolibacter were of particular interest as this genus was increased by all four crop families (Poaceae, Amaranthaceae, Asteraceae and Solanaceae) after growth in disrupted agroecosystems. Notably, however, this genus was not increased in either NPCK (disrupted/undisrupted) which likely indicates a plant-symbiotic nature of Luteolibacter. Further the genus falls within the Verrucomicrobia phylum, a bacterial phylum known to be present in varying plant-soil ecosystem interactions [44, 86-88] in addition to being reported in the rhizospheres differing-family crops (Poaceae, Amaryllildaceae, and Solanaceae) [44]. Therefore, the bacterial abundance increases shared by crops of different families may be worth investigating as novel and generalist PGPRs in further experimentation.

\section{Declarations}

Funding This research was supported by Colorado State University Agricultural Experiment Station and a USDA Cooperative Agreement.

Conflict of Interest Authors declare no conflicts of interest.

Availability of Data and Material Data and code can be made available from the corresponding author(s) upon reasonable request.

Authors' contributions All authors contributed to the study conception and design. M.D. conducted the experiment under the guidance of J.V. and D.M. M.D. wrote the manuscript with revisions provided by J.V. and D.M. M.D. conducted statistical analyses of the data in this experiment and prepared all images, figures, and Supplementary Information for the results of this study. All authors reviewed the manuscript prior to submission.

Ethics approval Not applicable. 
Consent to participate Not applicable.

Consent for publication Authors consent to publication.

Acknowledgments Authors would like to thank Dr. Tiffany Weir and Dr. loannis Minas for their assistance in manuscript revision.

\section{References}

1. Trivedi P, Schenk PM, Wallenstein MD, \& Singh BK. Microbes, Big Yields: enhancing food crop production with biological solutions. Microb Biotechnol 2017 10(5): 999-1003. https://dx.doi.org/10.1111\%2F1751-7915.12804

2. Maron PA, Sarr A, Kaisermann A, Lévêque J, Mathieu O, Guigue J, Karimi B, Bernard L, Dequiedt S, Terrat S, Chabbi A, Ranjard L. High microbial diversity promotes soil ecosystem functioning. Appl. Environ. Microbiol. 2018, 84(9): e02738-17. https://doi.org/10.1128/aem.02738-17

3. He Y, Pantigoso H, Vivanco JM. Co-Inoculation of Bacillus Sp. and Pseudomonas Putida at Different Development Stages Acts as a Biostimulant to Promote Growth, Yield and Nutrient Uptake of Tomato." Jol Appl Microbiol, 2019, 127(1): 196-207. https://doi.org/10.1111/jam.14273

4. Chaparro JM, Badri DV, Vivanco JM. Rhizosphere Microbiome Assemblage Is Affected by Plant Development." The ISME journal, 2014, 8, 790-80. https://doi.org/10.1038/ismej.2013.196

5. Deng S, Wipf HM, Pierroz G, Raab TK, Khanna R, Coleman-Derr, DA. Plant Growth-Promoting Microbial Soil Amendment Dynamically Alters the Strawberry Root Bacterial Microbiome. Sci Rep 2019, 9, 17677. https://doi.org/10.1038/s41598-019-53623-2

6. Zhao Q, Xiong W, Xing Y, Sun Y, Lin X, Dong Y. Long-Term Coffee Monoculture Alters Soil Chemical Properties and Microbial Communities. Sci Rep 2018, 8, 6116. https://doi.org/10.1038/s41598-01824537-2

7. McDonald BA, Stukenbrock EH. Rapid Emergence of Pathogens in Agro-Ecosystems: Global Threats to Agricultural Sustainability and Food Security. Phil. Trans. R. Soc. B 2016, 371, 20160026. https://doi.org/10.1098/rstb.2016.0026

8. Guo Z, Han J, Li J, Xu Y, Wang X. Effects of long-term fertilization on soil organic carbon mineralization and microbial community structure. PLoS ONE, 2019, 14(1): e0211163. https://doi.org/10.1371/journal.pone.0211163

9. Lin W, Lin M, Zhou H, Wu H, Li Z, Lin W. The Effects of Chemical and Organic Fertilizer Usage on Rhizosphere Soil in Tea Orchards." PloS one, 2019, 14(5), e0217018. https://dx.doi.org/10.1371\%2Fjournal.pone.0217018

10. Patil B, Hiremath SM, Nadagouda BT, Potdar MP. Impact of Fertigation and Target Yield Levels on Soil Microbial Biomass and Cane Yield of Ratoon Sugarcane. Int. J. Curr. Microbiol. App. Sci. 2017, 6(4): 1718-1722. http://dx.doi.org/10.20546/ijcmas.2017.604.206 
11. Sande D, Mullen J, Wetzstein M, Houston J. “Environmental Impacts from Pesticide Use: a Case Study of Soil Fumigation in Florida Tomato Production." International journal of environmental research and public health. MDPI, 2011, 8(12): 4649-4661.

https://dx.doi.org/10.3390\%2Fijerph8124649

12. Jacobsen CS, Hjelms $\varnothing$ MH. Agricultural Soils, Pesticides and Microbial Diversity. Curr. Opin. Biotechnol. 2014. (27): 15-20. https://doi.org/10.1016/j.copbio.2013.09.003

13. Bakker MG, Manter DK, Sheflin AM, Weir TL, Vivanco JM. Harnessing the rhizosphere microbiome through plant breeding and agricultural management. Plant and Soil 2012. 360, 1-13. https://doi.org/10.1007/s11104-012-1361-x

14. Broeckling CD, Broz AK, Bergelson J, Manter DK, and Vivanco JM. Root Exudates Regulate Soil Fungal Community Composition and Diversity. Appl. Environ. Microbiol. 2008. https://doi.org/10.1128/aem.02188-07

15. Martínez-García LB, Korthals G, Brussaard L, Jørgensen HB De Deyn, GB. Organic Management and Cover Crop Species Steer Soil Microbial Community Structure and Functionality along with Soil Organic Matter Properties. Agriculture, Ecosystems \& Environment. 2018. (263): 7-17. https://doi.org/10.1016/j.agee.2018.04.018

16. Sugiyama A, Vivanco JM, Jayanty SS, Manter DK. Pyrosequencing assessment of soil microbial communities in organic and conventional potato farms. Plant Disease, 2010. 94:13291335. https://doi.org/10.1094/PDIS-02-10-0090

17. Li K, DiLegge MJ, Minas IS, Hamm A, Manter DK, Vivanco JM. Soil Sterilization Leads to ReColonization of a Healthier Rhizosphere Microbiome. Rhizosphere. 2019, (12): 100176. https://doi.org/10.1016/j.rhisph.2019.100176

18. Peralta AL, Sun Y, McDaniel MD, Lennon JT. Crop Rotational Diversity Increases Disease Suppressive Capacity of Soil Microbiomes. Ecological Society of America. 2018. https://doi.org/10.1002/ecs2.2235

19. Wolf DC, Skipper HD. Soil Sterilization. Methods of Soil Analysis: Part 2-Microbiological and Biochemical Properties. Soil Science Society of America, 1994. 10.2136/sssabookser5.2

20. Trabelsi D, Mhamdi R. Microbial Inoculants and Their Impact on Soil Microbial Communities: a Review. BioMed Res Int. 2013, 863240. https://doi.org/10.1155/2013/863240

21. Qiu M, Li S, Zhou X, Cui X, Vivanco JM, Zhan N, Shen Q, Zhang R. De-coupling of root-microbiome associations followed by antagonist inoculation improves rhizosphere soil suppressiveness. Biol. and Fert. of Soils 2013, (50):217-224. https://doi.org/10.1007/s00374-013-0835-1

22. van Elsas JD, Chiurazzi M, Mallon CA, Elhottova D, Kristufek A, Salles, JF. Microbial Diversity Determines the Invasion of Soil by a Bacterial Pathogen. Proc Natl Acad Sci U S A 2012, 109(4): 1159-1164. https://doi.org/10.1073/pnas.1109326109

23. Chambers JM, Freeny, AE, Heiberger, RM. Analysis of variance; designed experiments. Statistical models in S. Routledge, 2017. 145-193. 
24. Klindworth A, Pruesse E, Schweer T, Peplies J, Quast C, Horn M, Glöckner FO. Evaluation of general $16 \mathrm{~S}$ ribosomal RNA gene PCR primers for classical and next-generation sequencing-based diversity studies. Nucleic Acids Res. 2013 Jan 7;41(1): e1. https://doi.org/10.1093/nar/gks808

25. Rohland N, Reich, D. Cost-effective, high-throughput DNA sequencing libraries for multiplexed target capture. Genome Res, 2012, (22):939-946. https://doi.org/10.1101/gr.128124.111

26. Faircloth, B and T Glenn. Ecol. And Evol Biology, UCLA. (2011) Serapure_v2.2.

27. Callahan BJ, McMurdie PJ, Rosen MJ, Han AW, Johnson AJ, Holmes, SP. DADA2: High-resolution sample inference from Illumina amplicon data. Nat. Methods, 2016. 13(7): 581-583. https://doi.org/10.1038/nmeth.3869

28. Martin M. (cutadept): Cutadapt removes adapter sequences from high-throughput sequencing reads. EMBnet.journal, 2011. 17, 10-12. https://doi.org/10.14806/ej.17.1.200

29. Oksanen JF, Blanchet G, Friendly M, Kindt R, Legendre P, McGlinn D, Minchin PR, O'Hara RB, Simpson GL, Solymos P, Stevens MHH, Szoecs E, Wagner H. vegan: Community Ecology Package. R package version 2.5-6. 2019

30. McMurdie PJ, Holmes S. phyloseq: An R Package for Reproducible Interactive Analysis and Graphics of Microbiome Census Data. PLoS ONE. 2013. 8(4): e61217. https://doi.org/10.1371/journal.pone.0061217

31. Manter DK, Korsa M, Tebbe C, Delgado JA. myPhyloDB: a local web server for the storage and analysis of metagenomic data. Database (Oxford) J. Biol. Databases Curation, 2016. https://doi.org/10.1093/database/baw037

32. Bardou P, Mariette J, Escudlié F, Djemiel C, Klopp C. jvenn: an interactive Venn diagram viewer. $B M C$ Bioinformatics 2014, 15:293 doi:10.1186/1471-2105-15-293. https://doi.org/10.1186/1471-2105-15293

33. Anderson BH, Magdoff FR. Autoclaving soil samples affects algal-available phosphorus. J. Environ. Qual. 2005, 34, 1958-1963. https://doi.org/10.2134/jeq2005.0024

34. Wang Y, Xu Y, Huang Q, Liang X, Sun Y, Qin X, Zhao L. Effect of sterilization on cadmium immobilization and bacterial community in alkaline soil remediated by mercapto-palygorskite. Environ. Pollution. 2021, 273, 116446. https://doi.org/10.1016/j.envpol.2021.116446

35. Chaparro JM, Sheflin AM, Manter DK, Vivanco JM. Manipulating the soil microbiome to increase soil health and plant fertility. Biol Fertil Soils 2012, (48): 489-499. https://doi.org/10.1007/s00374-0120691-4

36. Krauss J, Gallenberger I, Steffan-Dewenter I. Decreased functional diversity and biological pest control in conventional compared to organic crop fields. PLoS One, 2011; 6: e19502. https://doi.org/10.1371/journal.pone.0019502

37. Nicholson WL, Munakata N, Horneck G, Melosh HJ, Setlow, P. Resistance of Bacillus Endospores to Extreme Terrestrial and Extraterrestrial Environments. Micro. and Mol. Biol. Revs. 2000; 64(3): 548-72. https://dx.doi.org/10.1128\%2Fmmbr.64.3.548-572.2000 
38. Yadav AN, Sachan SG, Verma P, Saxena AK. Prospecting cold deserts of north western Himalayas for microbial diversity and plant growth promoting attributes. J. Biosci. Bioeng. 2015; 119(6), 683-693. https://doi.org/10.1016/j.jbiosc.2014.11.006

39. Bjørnlund L, Liu M, Rønn R, Christensen S, Ekelund F. Nematodes and protozoa affect plants differently, depending on soil nutrient status. Eu Jol of Soil Biol 2012; (50): 28-31. http://dx.doi.org/10.1016/j.ejsobi.2011.11.012

40. Kumar S, Suyal DC, Bhoriyal M, Goel R. Plant growth promoting potential of psychrotolerant Dyadobacter $s p$. for pulses and finger millet and impact of inoculation on soil chemical properties and diazotrophic abundance. Journal of Plant Nutrition, 2018; 41(8), 1035-1046. https://doi.org/10.1080/01904167.2018.1433211

41. Singh N, Marwa N, Mishra SK, Mishra J, Verma PC, Rathaur S, Singh N. Brevundimonas diminuta mediated alleviation of arsenic toxicity and plant growth promotion in Oryza sativa L. Ecotoxicol. and Environ. Safety, 2016; (125): 25-34. https://doi.org/10.1016/j.ecoenv.2015.11.020

42. Raweekul W, Wuttitummapor S, Sodchuen W, Kittiwongwattana C. Plant growth promotion by endophytic bacteria isolated from rice (Oryza sativa) Thammasat Int Jol of Sci and Tech, 2016; 21(1). https://doi.org/10.14456/tijsat.2016.2

43. da Rocha UN, Plugge CM, George I, van Elsas JD, van Overbeek LS. The Rhizosphere Selects for Particular Groups of Acidobacteria and Verrucomicrobia PLOS ONE, 2013; 8(12): e82443. https://doi.org/10.1371/journal.pone.0082443

44. Jorquera MA, Shaharoona B, Nadeem SM, Mora MDLL, Crowley DE. Plant Growth-Promoting Rhizobacteria Associated with Ancient Clones of Creosote Bush (Larrea tridentata). Microb. Ecol., 2012; 64(4), 1008-1017. https://doi.org/10.1007/s00248-012-0071-5

45. Kim SJ, Weon HY, Kim YS, Moon JY, Seok SJ, Hong SB, Kwon SW. Caenimonas terrae sp nov, isolated from a soil sample in Korea, and emended description of the genus Caenimonas Ryu et al. 2008 Jol. Microbiol. 2012; 50(5), 864-868. https://doi.org/10.1007/s12275-012-1587-6

46. Tan, Y, Wang Y, Wang D, Wang G, Zheng S. Sphingoaurantiacus capsulatus sp nov, isolated from mountain soil, and emended description of the genus Sphingoaurantiacus Int. J. System. Evol. Microbiol. 2016; 66(12), 4930-4935. https://doi.org/10.1099/ijsem.0.001447

47. Dahal RH, Kim J. Rhabdobacter roseus gen nov, sp nov, isolated from soil. Int. J. System. Evol. Microbiol, 2016; 66(1), 308-314. https://doi.org/10.1099/ijsem.0.000714

48. Anandham R, Premalatha N, Jee HJ, Weon HY, Kwon SW, Krishnamoorthy R, Gandhi PI, Kim YK, Gopal NO. Cultivable bacterial diversity and early plant growth promotion by the traditional organic formulations prepared using organic waste materials Int. J. Recucl. Org. Waste Agric., 2015; 4(4), 279-289. https://doi.org/10.1007/s40093-015-0107-1

49. Subrahmanyam G, Kumar A, Sandilya SP, Chutia M, Yadav AN. Diversity, Plant Growth Promoting Attributes, and Agricultural Applications of Rhizospheric Microbes. In book: Yadav A, Singh J, Rastegari A, Yadav N (eds) Plant Microbiomes for Sustainable Agriculture Sustainable Development and Biodiversity, vol 25 Springer, Cham 2020. http://dx.doi.org/10.1007/978-3-030-38453-1_1 
50. Moronta-Barrios F, Gionechetti F, Pallavicini A, Marys E, Venturi V. Bacterial microbiota of rice roots: 16S-based taxonomic profiling of endophytic and rhizospheric diversity, endophytes isolation and simplified endophytic community. Microorganisms 2018; 6(1):14. https://dx.doi.org/10.3390\%2Fmicroorganisms6010014

51. Nor MNM, Sabaratnam V, Tan GYA. Devosia elaeis sp nov, isolated from oil palm rhizospheric soil Int. J. System. Evol. Microbiol., 2017; 67(4), 851-855. https://doi.org/10.1099/ijsem.0.001683

52. Rashid S, Charles TC, Glick BR. Isolation and Characterization of New Plant Growth-Promoting Bacterial Endophytes" App. Soil Ecol., 2011; (61): 217-224. https://doi.org/10.1016/j.apsoil.2011.09.011

53. Carvalhais LC, Dennis PG, Schenk PM. Plant defence inducers rapidly influence the diversity of bacterial communities in a potting mix. App. Soil Ecol., 2014; (84): 1-5. https://doi.org/10.1016/j.apsoil.2014.06.011

54. Xiao X, Fan M, Wang E, Chen W, Wei, G. Interactions of plant growth-promoting rhizobacteria and soil factors in two leguminous plants. App/ Microbiol Biotechnol 2017; (101): 8485-8497. https://doi.org/10.1007/s00253-017-8550-8

55. Alkhnajari, A. Microbial diversity of buckwheat rhizosphere in wirework-infested and non-infested soils using metagenomics [Island Scholar Master's thesis] 2019; University of Prince Edward Islands

56. Reis VM, Teixeira KRDS. Nitrogen fixing bacteria in the family Acetobacteraceaeand their role in agriculture. Jol Basic Microbol. 2015; 55(8), 931-949. https://doi.org/10.1002/jobm.201400898

57. Davidov Y, Jurkevitch E. Diversity and evolution of Bdellovibrio-and-like organisms (BALOs), reclassification of Bacteriovorax starrii as Peredibacter starrii gen nov, comb nov, and description of the Bacteriovorax-Peredibacter clade as Bacteriovoracaceae fam nov. Int. J. System. Evol. Microbiol, 2004; 54(5), 1439-1452. https://doi.org/10.1099/ijs.0.02978-0

58. Eltlbany N, Baklawa M, Ding GC, Nassal D, Weber N, Kandeler E, Neuman G, Ludewig U, van Overbeek $\mathrm{L}$, Smalla K. Enhanced tomato plant growth in soil under reduced $\mathrm{P}$ supply through microbial inoculants and microbiome shifts FEMS. Microbiol. Ecol., 2019; 95(9). https://doi.org/10.1093/femsec/fiz124

59. Bonanomi G, Cesarano G, Antignani V, Maio CD, Filippis FD, \& Scala F. Conventional farming impairs Rhizoctonia solani disease suppression by disrupting soil food web. J. Phytopathol., 2018; 166(9), 663-673. https://doi.org/10.1111/jph.12729

60. Madhaiyan M, Poonguzhali S, Senthilkumar M, Pragatheswari D, Lee JS, Lee KC. Arachidicoccus rhizosphaerae gen nov, sp nov, a plant-growth-promoting bacterium in the family Chitinophagaceae isolated from rhizosphere soil. Int. J. System. Evol. Microbiol., 2014; 65(Pt 2), 578-586. https://doi.org/10.1099/ijs.0.069377-0

61. Kämpfer P, Lodders N, Falsen E. Hydrotalea flava gen nov, sp nov, a new member of the phylum Bacteroidetes and allocation of the genera Chitinophaga, Sediminibacterium, Lacibacter, Flavihumibacter, Flavisolibacter, Niabella, Niastella, Segetibacter, Parasegetibacter, Terrimonas, 
Ferruginibacter, Filimonas and Hydrotalea to the family Chitinophagaceae fam nov. Int. J. System. Evol. Microbiol, 2011; 61(3): 518-523. https://doi.org/10.1099/ijs.0.023002-0

62. Kim MK, Kim YJ, Cho DH, Yi TH, Soung NK, Yang DC. Solimonas soligen nov, sp nov, isolated from soil of a ginseng field. Int. J. System. Evol. Microbiol., 2007; 57(11), 2591-2594.

https://doi.org/10.1099/ijs.0.64938-0

63. Rojas-Solís D, Zetter-Salmón E, Contreras-Pérez M, Rocha-Granados MDC, Macías-Rodríguez L, Santoyo G. Pseudomonas stutzeri E25 and Stenotrophomonas maltophilia CR71 endophytes produce antifungal volatile organic compounds and exhibit additive plant growth-promoting effects. Biocatalysis and Agri. Biotechnol., 2018; 13, 46-52. https://doi.org/10.1016/j.bcab.2017.11.007

64. Pham VTK, Rediers H, Ghequire MGK, Nguyen HH, De Mot R, Vanderleyden J, Spaepen S. The plant growth-promoting effect of the nitrogen-fixing endophyte Pseudomonas stutzeri A15. Arch Microbiol, 2017; 199, 513-517. https://doi.org/10.1007/s00203-016-1332-3

65. Preston GM. Plant perceptions of plant growth-promoting Pseudomonas Phil Trans R Soc Lond, 2004; B359907-918. https://doi.org/10.1098/rstb.2003.1384

66. Berg B, Hofsten BV, Pettersson G. Electronmicroscopic Observations on the Degradation of Cellulose Fibres by Cellvibrio fulvus and Sporocytophaga myxococcoides. J. Applied Bacteriol., 1972; 35(2), 215-219. https://doi.org/10.1111/j.1365-2672.1972.tb03692.x

67. Liew KJ, Teo SC, Shamsir MS, Sani RK, Chong CS, Chan KG, Goh KM. Complete genome sequence of Rhodothermaceae bacterium RA with cellulolytic and xylanolytic activities. 3 Biotech, 2018; (8): 376. https://doi.org/10.1007/s13205-018-1391-z

68. Li S, Peng M, Liu Z, Shah SS. The Role of Soil Microbes in Promoting Plant Growth. Mol. Microbiol. Res. 2017; (7)4: 30-37. http://dx.doi.org/10.5376/mmr.2017.07.0004

69. Ehrig A, Müller RH, Babel W. Isolation of phenoxy herbicide-degrading Rhodoferax species from contaminated building material. Acta Biotechnologica, 1997; 17(4), 351-356. https://doi.org/10.1002/abio.370170411

70. Johansen J, Binnerup S. Contribution of Cytophaga-like Bacteria to the Potential of Turnover of Carbon, Nitrogen, and Phosphorus by Bacteria in the Rhizosphere of Barley (Hordeum vulgare $L$ ). Microbial Ecology, 2002); 43(3), 298-306. https://doi.org/10.1007/s00248-002-2006-z

71. Barman D, Dkhar MS. Plant Growth-Promoting Potential of Endophytic Bacteria Isolated from Costus speciosus in Tropical Deciduous Forest of Eastern Himalaya. Proc. Natl. Acad. Sci., 2018; India, Sect. B. Biol Sci. https://doi.org/10.1007/s40011-018-0998-5

72. Pandey C, Bajpai VK, Negi YK, Rather IA, Maheshwari DK. Effect of Plant Growth Promoting Bacillus Spp. on Nutritional Properties of Amaranthus Hypochondriacus Grains. Saudi Journal of Biological Sciences, 2018; (25)6: 1066-1071. https://doi.org/10.1016/j.sjbs.2018.03.003

73. Sansinenea E. Bacillus spp.: As Plant Growth-Promoting Bacteria. In: Singh H., Keswani C., Reddy M., Sansinenea E., García-Estrada C. (eds) Secondary Metabolites of Plant Growth Promoting Rhizomicroorganisms. Springer, Singapore 2019. https://doi.org/10.1007/978-981-13-5862-3_11 
74. Akinrinlola RJ, Yuen GY, Adesemoye, AO. Evaluation of Bacillus Strains for Plant Growth Promotion and Predictability of Efficacy by In Vitro Physiological Traits. Intl J Microbiol. 2018; (3): 5686874. https://doi.org/10.1155/2018/5686874

75. Nieuwesteeg N. Biological control of fungal plant pathogens by tomato endosphere bacteria [Unpublished Master's Thesis] 2015; Wageningen University and Research Center

76. Madhaiyan M, Poonguzhali S, Lee JS, Senthilkumar M, Lee KC, Sundaram S. Mucilaginibacter gossypii sp nov and Mucilaginibacter gossypiicola sp nov, plant-growth-promoting bacteria isolated from cotton rhizosphere soils. Int. J. System. Evol. Microbiol., 2009; 60(10), 2451-2457. https://doi.org/10.1099/ijs.0.018713-0

77. Boonsnongcheep P, Nakashima T, Takahashi Y, Prathanturarug S. Diversity of Endophytic Actinomycetes Isolated from Roots and Root Nodules of Pueraria candollei Grah ex Benth and the Analyses of Their Secondary Metabolites. Chiang Mai J Sci 2017; 44(1): 1-14

78. Syranidou E, Christofilopoulos S, Politi M, Weyens N, Venieri D, Vangronsveld J, Kalogerakis $\mathrm{N}$. Bisphenol-A removal by the halophyte Juncus acutus in a phytoremediation pilot: Characterization and potential role of the endophytic community. Journal of Hazardous Materials, 2017; (323): 350358. https://doi.org/10.1016/j.jhazmat.2016.05.034

79. Tsavkelova EA, Klimova SY, Cherdyntseva TA, Netrusov Al. Microbial producers of plant growth stimulators and their practical use: A review. Appl Biochem Microbiol 2006; (42): 117-126. https://doi.org/10.1134/S0003683806020013

80. Gulmus E, Gormez A. Characterization and biotechnological application of protease from thermophilic Thermomonas haemolytica. Arch Microbiol 2020; (202): 153-159. https://doi.org/10.1007/s00203-019-01728-7

81. Wei Z, Gu Y, Friman VP, Kowalchuk GA, Xu Y, Shen Q, Jousset A. Initial soil microbiome composition and functioning predetermine future plant health. Sci Adv. 2019; 5(9). https://doi.org/ 10.1126/sciadv.aaw0759

82. Harrison JG, Parchman TL, Cook D, Gardner DR, Forister ML. A heritable symbiont and hostassociated factors shape fungal endophyte communities across spatial scales. Journal of Ecology. 2018;106(6):2274-2286. https://doi.org/10.1111/1365-2745.12967

83. Jones P, Garcia BJ, Furches A, Tuskan GA, Jacobson D. Plant Host-Associated Mechanisms for Microbial Selection. Front Plant Sci. 2019; 10:862. https://doi.org/10.3389/fpls.2019.00862

84. Aguirre-von-Wobeser E, Rocha-Estrada J, Shapiro LR, de la Torre M. Enrichment of Verrucomicrobia, Actinobacteria and Burkholderiales drives selection of bacterial community from soil by maize roots in a traditional milpa agroecosystem. PLOS ONE, 2018; 13(12): e0208852.

https://doi.org/10.1371/journal.pone.0208852

85. da Rocha UN, van Elsas JD, van Overbeek LS. Verrucomicrobia subdivision 1 strains display a difference in the colonization of the leek (Allium porrum) rhizosphere. FEMS Microbiol. Ecol., 2011; 78(2): 297-305. https://doi.org/10.1111/j.1574-6941.2011.01156.x 
86. da Rocha UN, van Elsas JD, van Overbeek LS. Real-Time PCR Detection of Holophagae (Acidobacteria) and Verrucomicrobia Subdivision 1 Groups in Bulk and Leek (Allium Porrum) Rhizosphere Soils. Jol. Microbiol. Methods, 2010; 83(2): 141-148. https://doi.org/10.1016/j.mimet.2010.08.003

\section{Tables}

Due to technical limitations, tables are only available as a download in the Supplemental Files section.

\section{Figures}

a)

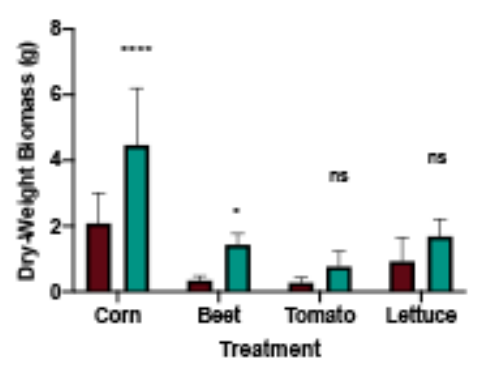

b)

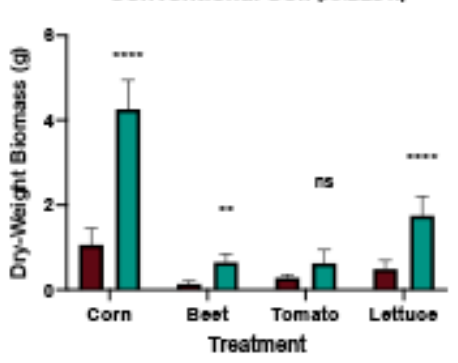

c)

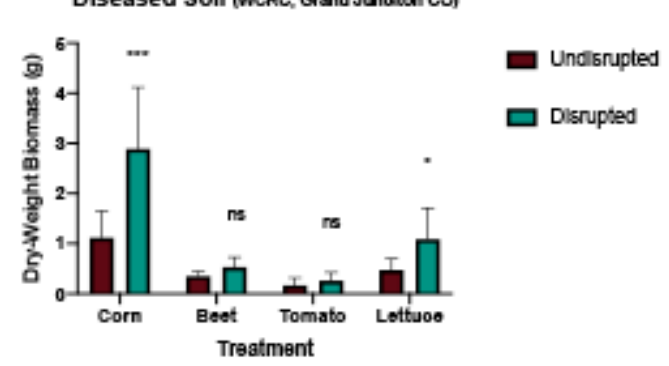

\section{Figure 1}

Mean dry-weight (DW) biomass measurements for each crop in each soil treatment $(n=10$ per crop per soil treatment, \pm standard deviation). (a) DW biomass results from crops grown in organic soil (b) DW biomass of crops grown in conventional soil (c) DW biomass of all crops grown in diseased soil. Red or blue bars represent the mean DW biomass for each crop in undisrupted or disrupted soil respectively. Significant differences between mean DW biomass of crops grown in disrupted or undisrupted soils are

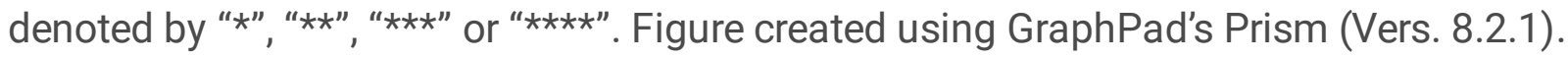
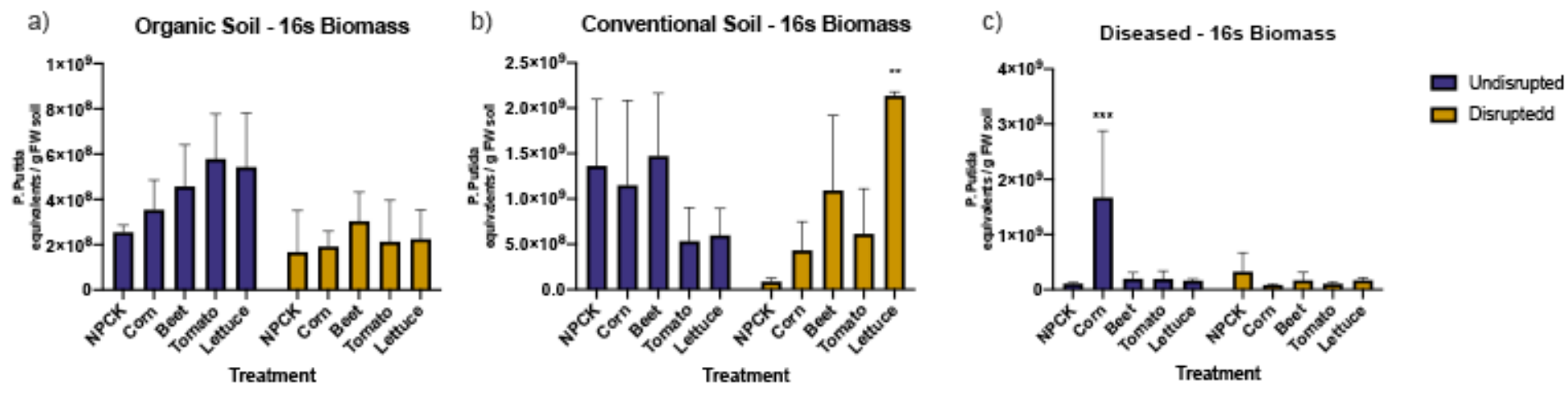

Figure 2

Mean bacterial cell counts per gram of fresh weight of each soil ( $\mathrm{n}=3$ per crop per soil treatment, \pm standard deviation). (a) bacterial cell counts resulting after crop growth in organic soil (b) bacterial cell 
counts resulting after crop growth in conventional soil (c) bacterial cell counts resulting after crop growth in diseased soil. Purple or yellow bars represent the mean number of bacterial cells for each crop grown in undisrupted or disrupted soils, respectively Bacterial cell counts can be interpreted as P putida equivalents per gram of fresh-weight soil Significant differences in cell counts between the NPCKs and crop treatments are denoted by “*”. Figure created using GraphPad's Prism (Vers. 8.2.1).

\section{Organic Soil}

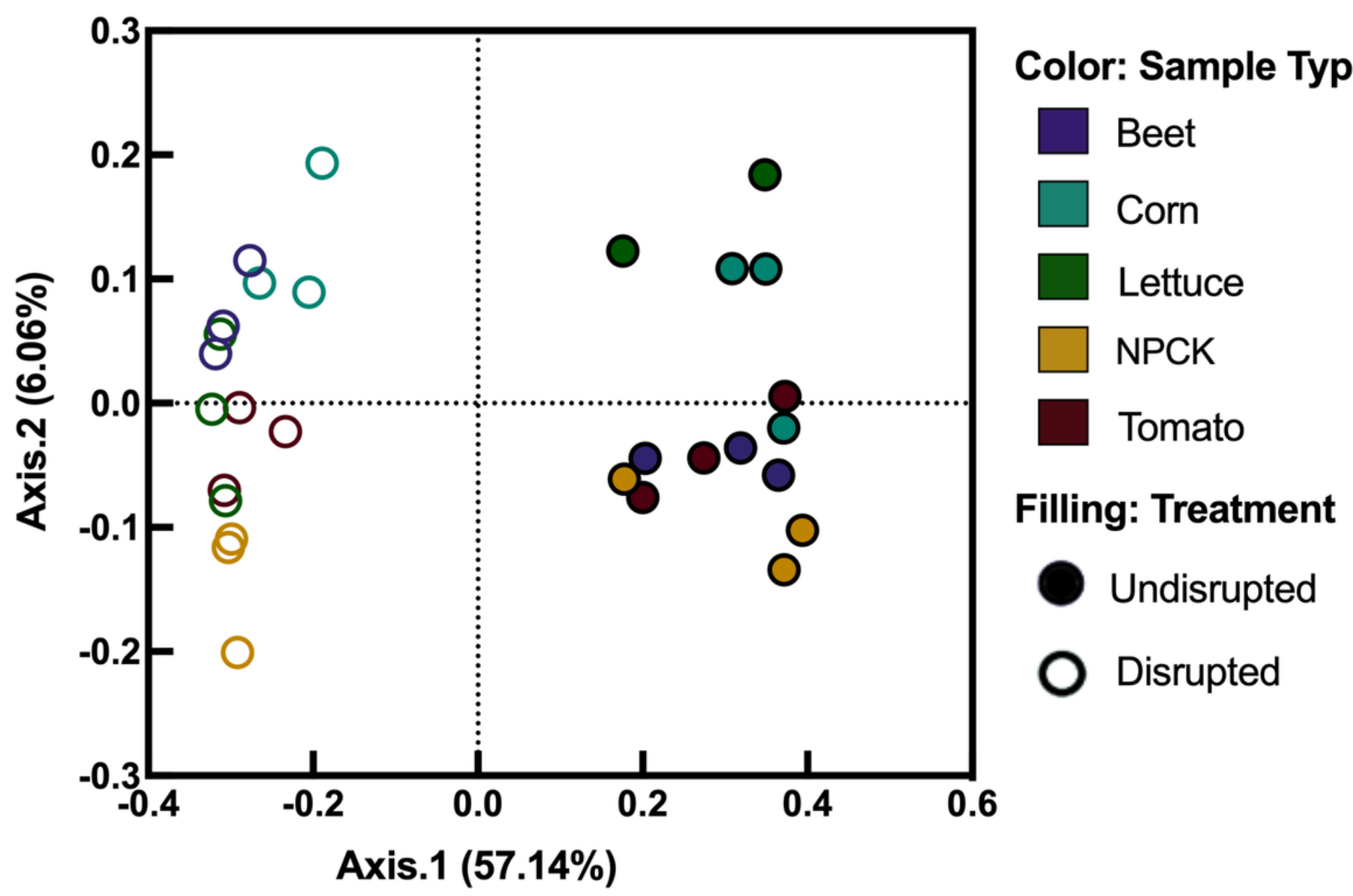

Figure 3

Principal Coordinate Analyses (PCoA) of rhizobacterial communities after crop growth in undisrupted and disrupted organic agroecosystem soils. Colored circles indicate samples treated with disruption, whereas hollow circles indicate undisrupted samples, respectively. Purple, teal, green, yellow, or red color represents rhizospheric samples from beet, corn, lettuce, NPCKs or tomato samples, respectively. Figure created using GraphPad's Prism (Vers. 8.2.1). 


\section{Conventional Soil}

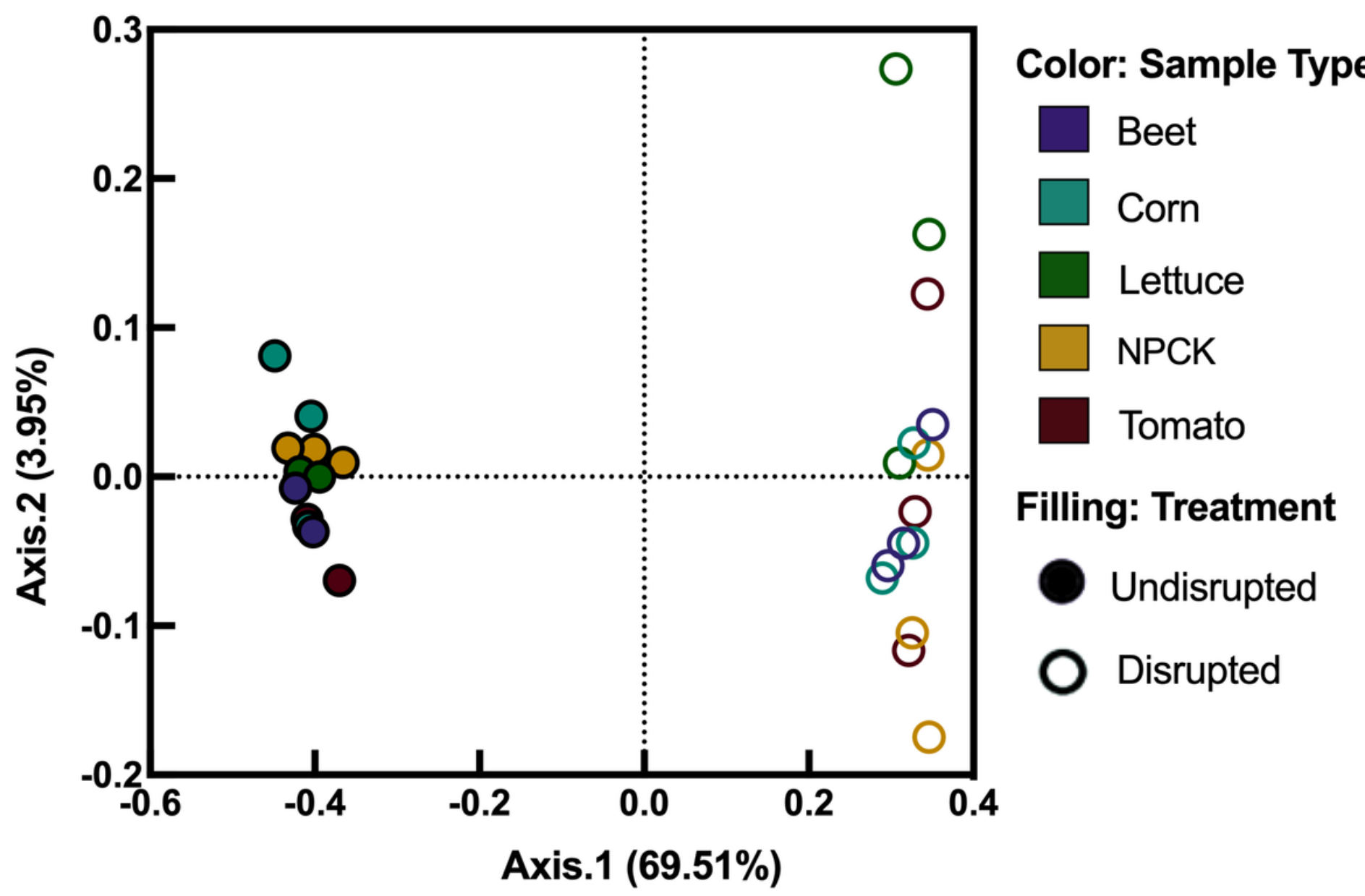

Figure 4

Principal Coordinate Analyses (PCoA) of rhizobacterial communities after crop growth in undisrupted and disrupted conventional agroecosystem soils. Colored circles indicate samples treated with disruption, whereas hollow circles indicate undisrupted soils, respectively. Purple, teal, green, yellow, or red color represents rhizospheric samples from beet, corn, lettuce, NPCKs or tomato samples, respectively. Figure created using GraphPad's Prism (Vers. 8.2.1). 


\section{Diseased Soil}

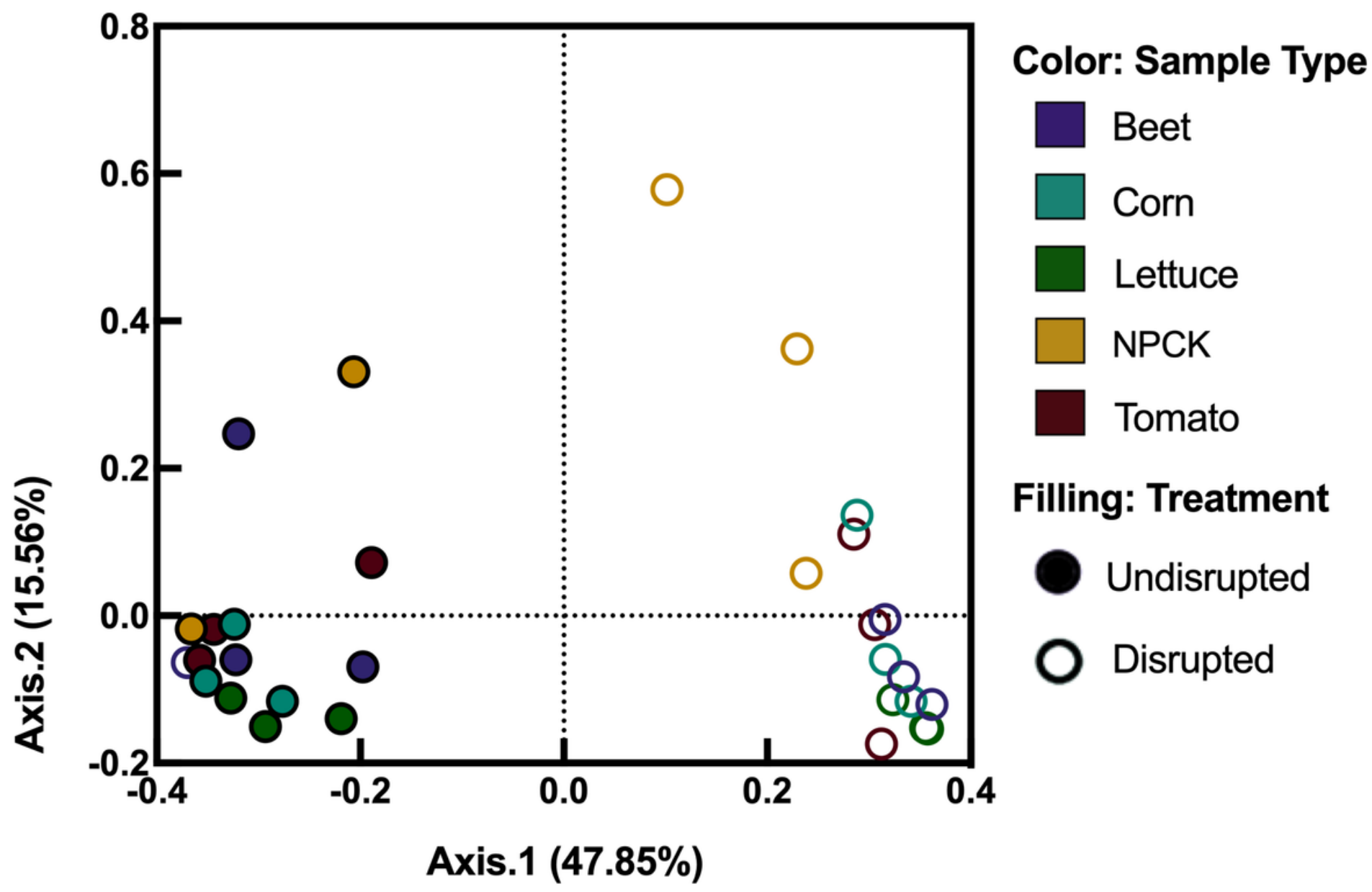

Figure 5

Principal Coordinate Analyses (PCoA) of rhizobacterial communities after crop growth in undisrupted and disrupted diseased agroecosystem soils. Colored circles indicate samples treated with disruption, whereas hollow circles indicate undisrupted soils, respectively. Purple, teal, green, yellow, or red color represents rhizospheric samples from beet, corn, lettuce, NPCKs or tomato samples, respectively. Figure created using GraphPad's Prism (Vers. 8.2.1). 
a)

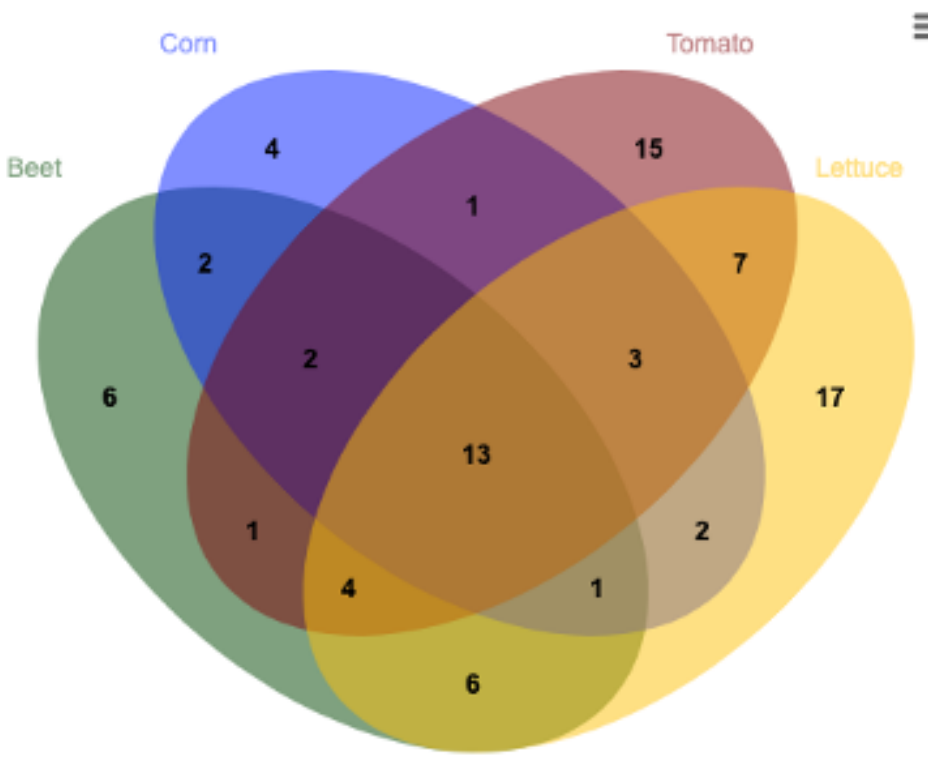

b)

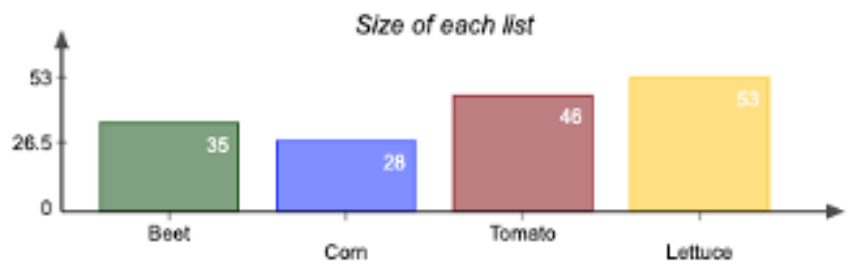

c)

Number of elements: specific (1) or shared by 2, 3,... lists

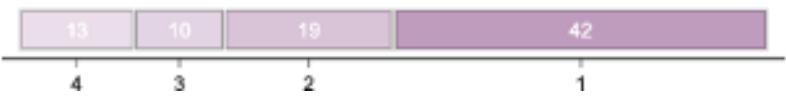

Figure 6

Venn diagram displaying the shared and unique bacterial reads from pooled crop rhizospheres after disruption. Bacterial reads comprising the figure were calculated from Tables 3-6. The list of full cropshared or crop specific bacterial reads can be visualized in Supplemental Table S5. (A) Venn diagrams noting the number of shared or specific genera for each crop (green = beet, blue = corn, red = tomato, yellow = lettuce). (B) Bar graph showing the size of bacterial increased in abundance by each crop after disruption. (C) Display showing the number of bacterial reads unique to one (42) or shared by two, three or four crops $(19,10,13$, respectively). Figure created using jvenn (2007).

\section{Supplementary Files}

This is a list of supplementary files associated with this preprint. Click to download.

- Supplementarylnformation.pdf

- Table1.xIsx

- Table2.xIsx

- Table3.xlsx

- Table4.xIsx 
- Table5.xIsx

- Table6.xlsx

- Table7.xlsx

- Table8.xlsx

- Table9.xlsx 